\title{
Investor Letters and the Everyday Practice of Finance in Nineteenth-century France
}

DOI:

10.1215/00161071-8806468

\section{Document Version}

Accepted author manuscript

Link to publication record in Manchester Research Explorer

\section{Citation for published version (APA):}

Yates, A. (2021). Investor Letters and the Everyday Practice of Finance in Nineteenth-century France. French Historical Studies, 77(2), 279-305. https://doi.org/10.1215/00161071-8806468

\section{Published in:}

French Historical Studies

\section{Citing this paper}

Please note that where the full-text provided on Manchester Research Explorer is the Author Accepted Manuscript or Proof version this may differ from the final Published version. If citing, it is advised that you check and use the publisher's definitive version.

\section{General rights}

Copyright and moral rights for the publications made accessible in the Research Explorer are retained by the authors and/or other copyright owners and it is a condition of accessing publications that users recognise and abide by the legal requirements associated with these rights.

\section{Takedown policy}

If you believe that this document breaches copyright please refer to the University of Manchester's Takedown Procedures [http://man.ac.uk/04Y6Bo] or contact uml.scholarlycommunications@manchester.ac.uk providing relevant details, so we can investigate your claim.

\section{OPEN ACCESS}


Investor Letters and the Everyday Practice of Finance in Nineteenth-century France

ABSTRACT: In the last decades of the nineteenth century, the Paris Exchange was the second largest in the world and engagement in financial markets had become 'popular' on a previously unknown scale. How ordinary people encountered, thought about, and navigated this new financial landscape has nevertheless proven elusive. This article analyzes everyday financial practice in the first age of global capital from the vantage of letters concerning their investments written by ordinary individuals. As the numbers of investors and bondholders in France grew, 'investor letters' - missives to financial, legal, and governmental authorities - proliferated. Their existence and concerns offer rich insights into how and with what effect France's financial markets were evolving at the end of the nineteenth century. These letters prompt us to reconsider the place of routine business correspondence in our studies of epistolary culture, and allow reflection on economic life as modest investors 'wrote upwards' and across the wealth gap of late nineteenth-century France.

RÉSUMÉ : Vers la fin du XIXème siècle, la Bourse de Paris était la deuxième place financière la plus importante au monde, et ses marchés étaient devenus "populaires » à une échelle jusque-là jamais atteinte. La manière dont les gens ordinaires ont réussi à s'orienter dans ce nouveau paysage se révèle difficile à saisir. Cet article analyse la pratique financière quotidienne de l'âge d'or de la globalisation du capital à partir du point de vue des particuliers écrivant à propos de leurs investissements. A mesure que le nombre d'investisseurs et d'obligataires a augmenté, ces «lettres d'investisseurs » adressées aux autorités financières, juridiques et gouvernementales se sont multipliées. Leur existence et leurs sujets de préoccupation offrent de riches informations sur l'évolution des marchés financiers français de la fin du XIXème siècle. Ces lettres nous incitent à reconsidérer la place de la correspondance commerciale dans la culture épistolaire, et en nous montrant comment de modestes investisseurs écrivent "vers le haut » de la hiérarchie économique et sociale, nous permettent d'accéder à des aspects méconnus de la vie économique de la fin du XIXème siècle français.

Martigues, 10 May 1886

\section{Dear Director,}

I do not have the honour of having made your acquaintance, yet I address myself to you, Sir, in the thought that you will be good enough to kindly offer some insight on the matter I am so bold as to discuss with you.

Here is the matter: Around four years ago, I read in a newspaper that a Parisian agency called Caisse de l'Epargne, Boulevard Rochechouard [sic] (since relocated to the Boulevard Magenta, 168) was selling bonds from the Crédit Foncier 3\% 1879 loan for payments of 10 francs per month, and that once subscribed, these bonds remained on deposit at the Bank of France until their full payment. This last payment made, one should receive the security.

I took one at that time. Always timely with my payments, I made the last payment of 75 francs including fees on March 29, 1886 - which means that I paid a total of 555 francs for the bond in question. I should have received the security immediately after and nothing doing - these gentlemen to whom I've written several times since continually put me off until the next week. 
Afraid that I've been taken for a dupe in this little matter, I would like, Sir, if you could be good enough to let me know if the bond in question Crédit Foncier 3\% 1879 no. 1.622.106 is currently in your possession and if not what you think about the affair.

Knowing no one in Paris, I write to you and dare hope Sir that you will not take offense that a private individual - but an Honest Man - writes to you and that despite the imbalance in our positions you will kindly honour me with a response reassuring me on my situation.

Gratefully yours, Monsieur le Directeur, and with sincere regards from your humble and very devoted servant,

Savournin

Wholesaler

Grande rue de Jonquière, Martigues (Fig. 1)

This letter to the director of the Bank of France is one of hundreds of missives penned by concerned investors to a range of national authorities in the final decades of the nineteenth century. ${ }^{1}$ Requesting information and advice, or reporting on potentially dubious operations, these letters can now be found in the archives of the country's banks, government ministries, and national police, filed in dossiers marked 'complaints', 'correspondence', or - as Savournin's letter might lead us to predict - 'fraud.' They came from across the country, the empire, and abroad, multiplying as individuals ventured their savings in foreign jurisdictions and as novice investors like Savournin encountered new sales methods and innovative financial instruments designed specifically to draw them into the market. They tell of modest investments intended for dowries and old age; of desires for security and ambitions for profit; of agents and circulars and advertising; of rumours about companies and anxieties about transactions. They are written on professional letterhead, invoices, lined paper, and the backs of cartes de visite, and come with prospectuses and embellished certificates (or the writer's best rendering of them) attached. In

\footnotetext{
${ }^{1}$ Archives de la Banque de France (hereafter ABF) 1060200105/61, Caisse de l'Epargne
} 


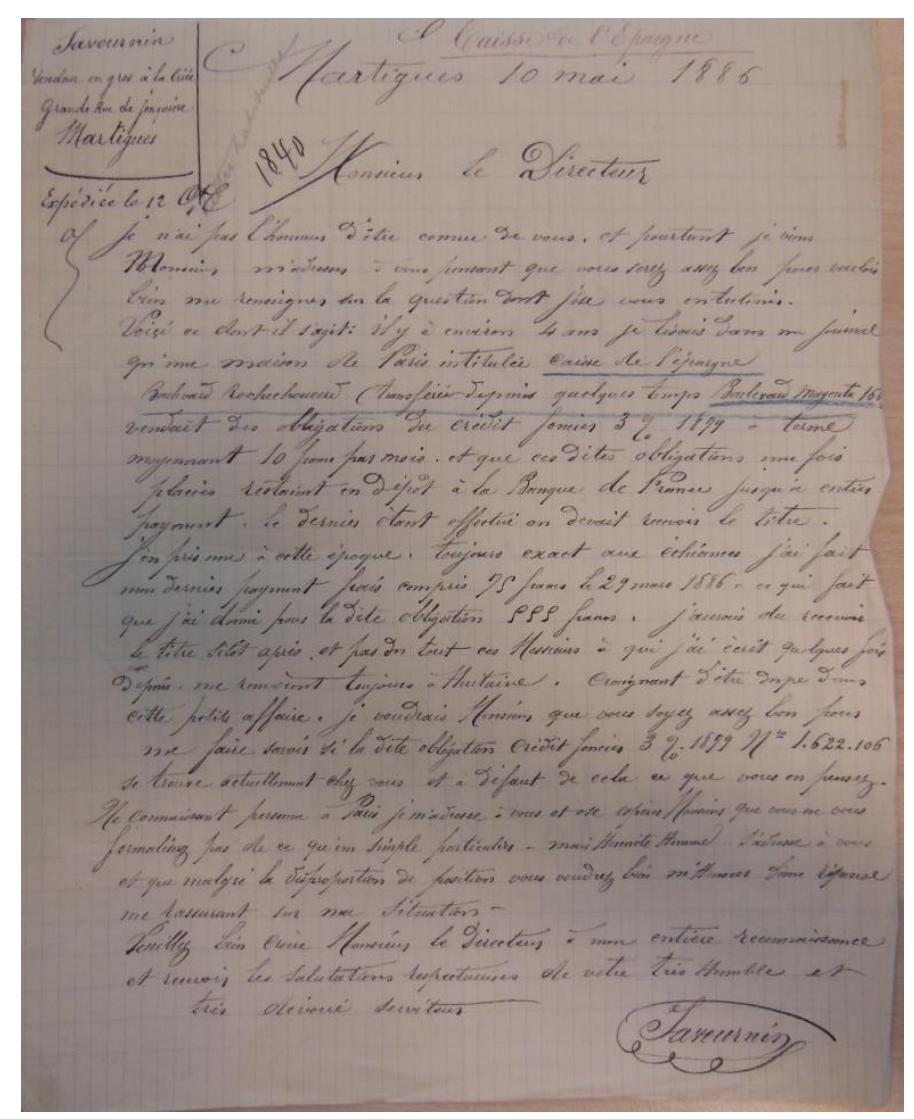

Figure 1: Letter from Savournin to the Director of the Bank of France, 10 May 1886. Source: Archives de la Banque de France

their words, their composition, and their form, these letters convey a host of acts, perspectives, and emotions that constituted the economic lives of ordinary people. Communicating these economic lives across physical, social, and cultural distance, investor letters staked claims to new modes of personal prosperity and collectively redefined the contours of the investing class.

The existence of these letters and the concerns they express offer a vital new perspective on the history of financial practice in the first age of global capital. They offer rich insights into how and with what effect France's financial markets were evolving at the end of the nineteenth century, and they point, too, to genres of financial practice that suggest the French experience of modern capitalism is of distinct historical and historiographic importance. In this period, the Paris Exchange - the Bourse - was the second largest in the world and engagement in financial 
markets had become 'popular' on a previously unknown scale. Minimum corporate share prices descended progressively between the 1860s and the 1890s, brokerage locations proliferated, and the number of financial circulars increased dramatically, traveling the country's road and rail lines along with a burgeoning new profession, the traveling securities' salesman. ${ }^{2}$ These changes built on the democratization of the market fueled by the expansion of the national debt and the state's adoption of direct marketing practices for its loans which, from the time of the Crimean War in 1855 , were issued directly to the saving public via an extensive network of public financial bureaus. ${ }^{3}$ In 1882 , the lowest possible subscription of la rente (as the national debt was known) was lowered to two francs - or, an investment of forty francs, which would generate a yearly income of two francs on a 5\% bond. This expanding national market involved new forms of written expression, coordination, and self-representation on the part of a widening class of participants.

How ordinary people encountered, thought about, and navigated this new financial landscape has proven elusive. ${ }^{4}$ Our histories of norms and institutions that shape nineteenthcentury French financial practice are rich, yet they rarely begin from the perspective of individual actors, let alone from those seemingly at the margins of engagement and influence. ${ }^{5}$ Nevertheless, the perspective of non-elite actors - even better, their views and agency - offers important insights for our understanding of the growth of modern financial infrastructures. As research in economic sociology and anthropology has shown, financial markets are social

\footnotetext{
${ }^{2}$ See Hautcoeur, Le Marché financier français, esp. chap. 9, and Freedeman, The Triumph of Corporate Capitalism. ${ }^{3}$ Todd and Yates, "Public Debt and Democratic Statecraft."

${ }^{4}$ For work in this direction, see Preda "The Rise of the Popular Investor;" Hochfelder, "Where the Common People Could Speculate." The figure of the individual investor - rather than individual investors themselves - is discussed in Preda "The Investor as a Cultural Figure." See also Poovey, "Writing about Finance."

${ }^{5}$ Cultural histories of French finance include Thompson The Virtuous Marketplace; Aglan, Feiertag, and Marec, Les Français et l'argent; Reffait. La Bourse dans le roman du second XIXe siècle. On legal histories of finance, see Stanziani, Dictionnaire historique de l'économie-droit; Hissung-Convert, La Spéculation boursière face au droit. On market institutions, see Hautcoeur and Riva, "The Paris Financial Market in the 19th Century."
} 
innovations, political products, and complex technical arrangements that involve tremendous work of invention, contestation, and legitimation. ${ }^{6}$ The process by which investment markets came to be understood as a quotidian element of modern citizens' economic lives - as well as the place of those markets in public conversations about modernization and globalization - was shaped in significant ways by small investors and their modest investments. Beginning from the perspective of everyday practice and lay knowledge shows the elaboration of local economic cultures and international markets to be multi-directional and multi-sited. Such an approach requires sources that expand the range of financial activities, experience, and appraisals available for interpretation.

In this article, I introduce and analyze investor letters as sources that allow us to reconcile the world of the material with the world of mentalité. ${ }^{7}$ While it remains on the periphery of our image and understanding of epistolary practice, business correspondence - an expansive genre, incorporating letters to partners and agents, bills to clients, and communications to lawyers, notaries, and middlemen for the management of estates - likely constituted the majority of letterwriting in mid-nineteenth-century France. ${ }^{8}$ Even family correspondence in the absence of business relations might be deeply materially oriented; Caroline Chotard-Loiret's study of one middle-class French family's correspondence across more than five decades of the nineteenth century found a preoccupation with material and economic affairs, at the expense of the private or intimate communications one might anticipate. ${ }^{9}$ Commercial correspondence has long proven a vital resource for historians of business, though its distance from the seemingly more intimate 'ego-documents' of diaries, autobiographies, or family letters has limited its appeal for historians

\footnotetext{
${ }^{6}$ MacKenzie, An Engine, not a Camera; Garcia-Parpet, "The Social Construction of a Perfect Market."

${ }^{7}$ Lipartito, "Connecting the Cultural and the Material in Business History."

${ }^{8}$ Poublan, "Affaires et passions. Des lettres parisiennes au milieu du XIXe siècle."

${ }^{9}$ Chotard-Lioret, "Correspondre en 1900."
} 
for whom personal writings are privileged terrains of self-fashioning and subjectivities. ${ }^{10}$ The routine, mundane, and utilitarian nature of business communications seemingly resists the current historical approach to correspondence, which, as Martyn Lyons summarizes, pursues letters as cultural artefacts and writing as cultural practice. ${ }^{11}$ However, recent work has extended the field of application for business correspondence, demonstrating persuasively how overlapping networks of family, emotion, and enterprise were both reflected in and constituted by 'business' letters. ${ }^{12}$ The ubiquity of such writings warrants inquiry into their potential as sites for the cultivation of a social self around matters of economic concern. ${ }^{13}$ As letters - rather than, say, journals or account books - these documents illuminate the communicative and social aspects of financial decision-making and capital management; they also reveal a compulsion to personalize and populate the otherwise abstract arena of "the market" that marked small investors' (though perhaps not only small investors') engagement with finance.

Here, I present material in which individual investors represent themselves - their aspirations, worries, and demands - as market actors to economic and political authorities. The letters are drawn from the corporate archives of the Bank of France, though I have consulted similar collections at the Crédit Foncier (the nation's central mortgage bank) as well as in ministerial collections, particularly the Ministry of Foreign Affairs, which received inquiries and remonstrances from investors with claims in foreign jurisdictions. They form a varied corpus, ranging considerably in style and sophistication and springing from different groups of writers.

\footnotetext{
${ }^{10}$ On terminology relating to sources of the self, see Summerfield, Histories of the Self.

${ }^{11}$ Lyons, Reading Culture and Writing Practices, esp. chap. 9. On business correspondence as a genre, see Locker, "“Sir, This Will Never Do."”,

${ }^{12}$ For examples of economic histories that interrogate family and business correspondence as sources, see Murphy, The Worlds of the Jeake Family of Rye; Popp and Holt, "Entrepreneurship and Being;" Cohen, "Love and Money in the Informal Empire." Merchant correspondence is central to the historiography of early modern commerce: Trivellato, The Familiarity of Strangers; Ditz, "Formative Ventures."

${ }^{13}$ On the various 'selves' cultivated through the act of letter-writing, see Rowe, "Writing Modern Selves."
} 
The letters to the Bank of France, for instance, are drawn from a collection of correspondence generated by a flurry of schemes in the 1880s that misleadingly deployed the Bank's name in order to attract inexperienced investors. Letters to the Ministry of Foreign Affairs, in contrast, included missives from organized groups of bondholders with significant social and financial capital. Despite these distinctions and specificities, the letters converge in their adherence to the conventions of business correspondence, and the correspondents share important attributes and goals - namely, to secure assistance in the management and security of their capital. It was in part through practices such as self-representation to authorities in these letters that writers could come to consider themselves as part of a specific political and economic demographic: investors and rentiers. Their collection and classification by national authorities allows the letters to be approached as a genre, rather than (only or primarily) as a source of information about specific individuals. In this way, they bear some similarity to the 'pauper letters' which have proven such rich sources for the history of the experience and representation of poverty in eighteenth- and nineteenth-century England, or perhaps even more closely, to the 'begging letters' that historian Scott Sandage used to reconstruct ideas around failure and economic justice in the nineteenthcentury United States. ${ }^{14}$ They are similar, too, to the 'lawyer's letters' or formulaic legal writings that Carolyn Steedman has used to establish a history of ordinary individuals' uses of the law in nineteenth-century England. ${ }^{15}$ While limited in their ability to represent a more general financial experience, these letters offer a vital entry point to the experience and emotion of investing for ordinary people, opening up a peopled and personal history of financial innovation and expansion.

\footnotetext{
${ }^{14}$ For key works in the well-developed literature on pauper letters and a 'new' history of poverty, see: King, Writing the Lives of the English Poor; Sokoll, "Writing for Relief"; Tomkins, “"I Mak Bould to Wrigt."”' On 'begging letters,' see Sandage, Born Losers, chap. 8.

${ }^{15}$ Steedman, "A Lawyer's Letter."
} 


\section{Writing Across the Wealth Gap}

France in the fin de siècle was a rentier society, dominated by a tranche of wealthy individuals enriched by returns generated by inherited wealth and enjoying close ties to political power. Economic disparities were radical, and increased as wealth concentration accelerated in the final decades of the nineteenth century. ${ }^{16}$ In 1900 , half of all French people, and $70 \%$ of Parisians, left no estates upon their deaths. ${ }^{17}$ Yet changes in financial practices and dispositions taking place beneath the rigid inequalities of the "long stagnation" were nevertheless significant. ${ }^{18}$ Among the population that did acquire assets to pass on to its descendants, securities ownership had transformed the distribution of wealth in French portfolios. Between 1880 and 1900, the value of 'movable wealth' - securities, furnishings, cash, etc. - surpassed that of real property in the estates of French households for the first time, and so far as Parisian portfolios were concerned (the city concentrated more of the nation's wealthy and poor families), 65\% of wealth was held in financial assets by $1900 .{ }^{19}$ The massive expansion of the country's savings banks - the caisses d'épargne - familiarized millions with national financial infrastructure and, particularly, ownership of the rente, into which savings above certain levels were transformed. The number of accounts increased by six times between 1870 and 1904, reaching 11.5 million, or about a quarter of the country's population. ${ }^{20}$ Some corporate shares by the last decade of the century were available for as little as 25 francs, and other securities were offered in fractions, payable in installments. A bond in the fourth tranche of the 1886 City of Paris loan, for example, was

\footnotetext{
${ }^{16}$ Piketty, Postel-Vinay, and Rosenthal, "Wealth Concentration in a Developing Economy."

${ }^{17}$ Piketty, Postel-Vinay, and Rosenthal, "Inherited vs. Self-made Wealth," 30.

${ }^{18}$ Breton, Broder, and Lutfalla, La longue stagnation en France.

${ }^{19}$ Piketty, Postel-Vinay, and Rosenthal, "Inherited vs. Self-made Wealth," 33.

${ }^{20}$ Neymarck Le Développement annuel de l'épargne française, 11. See also Christen-Lécuyer, Histoire sociale et culturelle des Caisses d'Épargne.
} 
initially priced at 376 francs in 1890, payable with 60 francs down and the remainder in instalments over the course of three years. While those with wealth to place in securities were clearly far from the poorest in society, these conditions ensured that they nevertheless comprised a more diverse group than at any previous point in the country's history.

The investment information upon which this expanding group could rely was a challenge to navigate; wildly abundant, it also ranged dramatically in form and quality, contributing to the frequency with which financial scandals marked the early Third Republic. ${ }^{21}$ In this context of potentially overwhelming, unreliable information and overstimulated imaginaries, individuals turned to institutions like the Bank of France to serve as wayfinders that could confirm the standing of enterprises boasting grand-sounding headquarters in Paris or advise on the dependability and legality of particular operations. As the mayor of the small town of Montceaux-1'Etoile (population 500) wrote in 1880, “every day we receive so many prospectuses from financial houses that it has become impossible for us to tell the good ones from the bad."22 This article explores a collection of 340 letters written to the bank between 1881 and 1906; 88\% were sent in the scandal-ridden 1880 s, and a full quarter - 88 letters - in 1883 alone. $^{23}$ Sometimes writers sought general financial guidance. One Mademoiselle Lamé from Lyon, for example, described as "very honest, an older woman who teaches lessons in the city," wrote her local branch of the Bank of France in 1881 to report her astonishment at the $25 \%$ return promised by a company called the Crédit Financier. Clearly tempted, she nevertheless acknowledged that "it would be a bad job of things to lose the fruit of twenty years of teaching in

\footnotetext{
${ }^{21}$ Bignon and Flandreau, "The Economics of Badmouthing," Garrigues, La République des hommes d'affaires; Bouvier, Les Deux scandales du Panama.

${ }^{22}$ ABF 1060199601/38.

${ }^{23}$ ABF $1060200105 / 61$ et 67.
} 
one moment of carelessness." ${ }^{24}$ But a particular influx of letters stemmed from the scores of new investors writing to check on securities that salesmen offering installment plans claimed (truthfully and otherwise) remained on deposit at the Bank of France until full payment. This was one of the ways that securities found their way into the hands of a broad consuming public: small agencies and itinerant salesmen pioneered sales on credit of small fractions of respectable securities, primarily the mortgage and municipal loans of the Crédit Foncier and bonds of the city of Paris. Operating in person and by mail, they left their clients with contracts, a payment schedule, and the promise that the security was safely awaiting them at the Bank of France once payments were completed. In total, these letters concern ninety-six different financial brokerages (some appearing only once, others generating letters in the double-digits) and came from 223 different cities and towns.

Considering the demographic and geographic origins of these letters in some detail helps establish as clearly as possible the social context of their production. Most letters were produced domestically, with about thirty originating from outside the country, principally from Switzerland and Belgium. Their geography broadly followed the country's population distribution, with more letters arriving from more populous and more urban departments. ${ }^{25}$ Yet this pattern did not hold consistently. For example, while it is not surprising that the highest number of letters (eighteen) arrived from Paris and the Seine department, departments sending the second and third highest number of letters were the Charente-Maritime and Marne, $23^{\text {rd }}$ and $28^{\text {th }}$ respectively in terms of population. ${ }^{26}$ In each case, the presence of large cities - La Rochelle and Reims - from which writers penned multiple letters seems to explain their unexpected

\footnotetext{
${ }^{24}$ ABF 1060200105/61, Crédit Financier

${ }^{25}$ Ministère du Travail et de la Prévoyance Sociale, Album graphique.

${ }^{26}$ Ministère de l'Agriculture et du Commerce, Direction de la statistique générale, Annuaire statistique de la France.
} 
showing. Similarly, while the relatively small European population of Algeria placed its departments low in the government's population accounting, writers in Algiers sent as many letters as were sent from Bordeaux, a city four times its size, making the Algerian territory the fourth most represented in the collection. Yet if cities seemed to have supported particular concentrations and distributions of letter writing, it remains that the vast majority of letters (72\%) came from towns with fewer than 10000 residents, and 22\% from villages smaller than 1 000. This reflects the population distribution in a country that remained overwhelmingly rural well into the twentieth century. A quarter of writers lived in towns that did not have their own post office, relying on mailmen or nearby centres to send and collect mail. ${ }^{27}$

Urbanity seems to have mattered particularly with regard to the gender distribution of letter writers. Women penned thirty letters in the collection, accounting for about $10 \%$ of the writers whose sex could be determined (which is 331/340). While the median size of the town or city from which men wrote was 2630 inhabitants, for women this figure rose to 10500 , suggesting the possibility that larger cities represented opportunities for financial activities that were particularly consequential for women's practices. Women faced constraints on their access to and control of property (especially marital property) in nineteenth-century France, and were physically barred from stock exchanges. ${ }^{28}$ These circumstances partially explain that historians to date have dedicated little substantial inquiry into their financial practices. ${ }^{29}$ Yet the investor

\footnotetext{
${ }^{27}$ Richez, "Le Facteur rural."

${ }^{28}$ Thompson, The Virtuous Marketplace.

${ }^{29}$ This contrasts with extensive historiography on gendered investment practices in the United States and United Kingdom. See Rutterford, Green, Maltby, and Owens, "Who Comprised the Nation of Shareholders?"; Robb, Ladies of the Ticker. Beachy, Craig, and Owens, Women, Business, and Finance contains only one chapter on France, while Laurence, Maltby, and Rutterford, Women and their Money contains none.
} 
letters they penned indicate previously unconsidered scope for women to understand themselves and engage as willful agents in the nineteenth-century financial marketplace. ${ }^{30}$

Assessing these letters from the perspective of their origins in modest towns distributed across much of the country (sixty-nine of eighty-seven departments, plus Algeria, are represented in the Bank's files), the national scope of the phenomenon becomes clear. So, too, does its social scope. Nearly $60 \%$ of writers listed their occupations (men were twice as likely to do so as women), adhering to correspondence protocols that counseled including one's profession in the address lines at the end of a letter. ${ }^{31}$ These are occasionally sufficiently specific to be good indicators of social standing - employee at the Belle Fermière department store in Rouen, for example. However, many are vague; the descriptors 'property owner' (ten writers), 'commercial agent' (fifteen), or 'merchant' (four) leave an individual's wealth, security, or independence indistinct. While this uncertainty means that the label may not fit in all cases, the overall impression is of a petty bourgeoisie, with all the fluidity the category entails. ${ }^{32}$ Letter-writer occupations showed concentrations in modest white-collar fields - education (seventeen), legal trades (thirteen), and administration (twenty) - alongside a diffusion of individuals occupied in small-scale manufacturing and trade (shoes, butchery, baking, grocers, tailors...), as both employees and independent producers. These are the mass of "petites situations" that made up the world of business and administration in late-nineteenth-century France, and whose politics were central to the Third Republic. ${ }^{33}$

\footnotetext{
${ }^{30}$ This chimes with new research on women as entrepreneurs in modern France. See Khan, "Invisible Women"; Labardin and Robic, "Epouses et petites entreprises"; Craig, Female Enterprise.

${ }^{31}$ Clément, Le Nouveau secrétaire. On correspondence manuals, see Dauphin, Prête-moi ta plume.

${ }^{32}$ Crossick and Haupt, Shopkeepers and Master Artisans.

${ }^{33}$ Nord, Paris Shopkeepers; Zdatny, The Politics of Survival.
} 
When such people turned to the assistance of the Bank of France, directly soliciting 'Monsieur le Gouverneur' or 'Monsieur le Directeur,' they were “writing upwards,” a term historian Martyn Lyons uses to characterize the various modes of supplication, complaint, and denunciation in which ordinary people place demands on those more powerful than themselves. ${ }^{34}$ The genre is complex. Broadly speaking, it fits well with established practices of clientelism and patronage that characterized social advancement in nineteenth-century France, for which solicitation of favours and places was an utterly conventional practice. ${ }^{35}$ In making a direct claim on the assistance of a national authority, writers were also embracing longstanding traditions of popular appeal premised on the presumed benevolence of rulers and faith in the ability of personal communication to overcome the obstacles and obfuscation of subordinate intermediaries. These demands for favours and services were thus premised on social hierarchies and operated through their rearticulation. Savournin made these distinctions of rank explicit in his letter, going a step beyond deferential platitudes (or might he be handling them clumsily, or glibly?) to express his faith that "in spite of the difference in our positions" the Governor of the Bank would not be offended at the interjection of a "mere individual" but recognize his virtues as an "Honest Man," worthy of time and assistance.

Yet the genre can support additional interpretations as well. The very bureaucracy that complicated access to authorities and de-personalized political and economic relations also invited more generalized, putatively egalitarian engagement from citizens. Many letters in this collection are brisk and business-like, resembling the models of efficient commercial correspondence that filled letter-writing guides, and reflecting a transactional equality governing the moment of (epistolary) exchange. Soliciting information and assistance from a public-facing

\footnotetext{
${ }^{34}$ Lyons, "Writing Upwards."

35 Agnès, "Le solliciteur et le pétitionnaire."
} 
authority in this fashion may imply different norms of reciprocity than those present in Savournin's invocations of merit and social obligation, a reciprocity more akin to routinized public service or the norms of market behaviour. ${ }^{36}$ As a brief note from a grocer in LabastideMurat (Lot) put it simply, "Monsieur le Directeur [...] I'm going to be a bit of a bother but if for my part I can do anything for you it would be my pleasure to be of service." ${ }^{37}$ Writers did claim a range of justifications for the Bank's particular attention, as we will see in more detail below; Joseph Arnaud wrote from Ventenac-d'Aude (near Narbonne) in 1883 "as a shareholder of the Bank of France", for example. ${ }^{38}$ But for many, the request was seemingly sufficiently ordinary not to require any exceptional self-presentations.

The more horizontal relations such writerly dispositions might affect or imply does not obscure that the very existence of these letters testifies to unequal social and economic situations. Not only did the party who penned the letter need something that the privileged position of the addressee enabled them to provide, but addressing oneself directly to the head of the Bank was also an acknowledgment that other avenues of access and power - ones through which better connected, more influential individuals routinely operated - were unavailable, perhaps even unthinkable. If, in the eyes of their authors, letters were not consistently transmitted upwards, they were certainly transmitted across a massive gap of wealth and privilege, one their authors' modest steps into the world of finance had no prospect of narrowing.

\section{Finance from the Margins}

These letters to the Bank of France can be divided into three principal types of inquiry. The first and most common consists of requests to verify the deposit of securities on which the letter-

\footnotetext{
36 Walton, "Capitalism's Alter Ego."

${ }^{37}$ ABF 1060200105/61, P. Lavayssière, Labastide-Murat, 10 March 1887.

38 ABF 1060200105/61, Petite Caisse d'Epargne Populaire
} 
writer was paying. Some writers had doubts after sending a few monthly installments to a brokerage, others (like Savournin) had paid for several years but then something changed that generated concern: they stopped receiving receipts, or the agency's monthly gazette, and worried that their tenth of a Crédit Foncier or their quarter of a City of Paris or City of Brussels bond was in jeopardy. The second type of inquiry sought information about the solidity of a firm before the writer made any commitment to buy. These are less frequent than letters that arrive after the decision but are still numerous. Finally, a number of letters arrived from individuals who were employed by a brokerage company, or were considering such employment, and solicited the assistance of the Bank in verifying the company's claims. For instance, Auguste Gaussin, a tax official in Juvisy-sur-Orge near Paris, wrote to inquire about the Docks Commerciaux et Agricoles after a representative's "insistent proposals" convinced him to take on a number of installment contracts to sell: "The man had barely left me when suspicions began to replace my gullibility [...] Monsieur le Gouverneur, can you please tell me whether I can, in complete confidence, undertake the sale of these contracts to the public?"39

Many of these letters are brief, even perfunctory, concerned with the essentials of the situation. They communicate the name of the brokerage or bank with which the writer transacted, the type of bond they had contracted to buy (often including its serial number), and request verification that the bond is in the Bank's possession. If the writer added a few sentences, they frequently summarize the particulars of the sales contract - ten francs a month for five years, for example - and their payment history. Yet an accumulation of even the sparest letters allows important details of investment practices and investing personas to emerge. When writers inquired after the reliability of particular companies - like when one G. Blachier from Saint-Uze

${ }^{39}$ ABF 1060200105/61, Docks Commerciaux et Agricoles (letter 1882) 
(Drôme) wrote with questions about the Banque Continentale, specifically "if one can place confidence in its operations with bonds of the Crédit Foncier, City of Paris and Lyon" - they demonstrated not only that they had encountered enticing investment opportunities (even in a town of 1300 inhabitants with no post office) but also that investment was a task they considered worthy of time and reflection. ${ }^{40}$ Occasionally, we learn specific details about this financial encounter. Madame Blu, from Ambérieu-en-Bugey (Ain), decided to deal with the Crédit Régional "on the basis of an advertisement," while Mademoiselle Lamé received a flyer in the mail, and others met salesmen whose "smooth talking" turned their heads. ${ }^{41}$ Writers often listed the family members in whose names bonds had been subscribed, inscribing the act of investment within the logic of household management and multi-generational accumulation strategies. The Widow Vandermensch wrote from Lille in 1887 that she had invested with La Participation Financière along with "several members of my family;" the family economy emerges as both means and end of financial practice. ${ }^{42}$

Both letters' content and their conditions of production signaled that investment had important social and collective aspects. From Algiers, Emile Kiéné justified his 1882 inquiry about the Docks Commerciaux by explaining that "many of my friends have engaged in the same operation," while a year later from Bordj Menaïel to the east, three men wrote together to seek information on the Banque Victoria, which had lately sold them each a quarter City of Paris bond and a tenth of a Crédit Foncier on a five-francs-a-month plan. ${ }^{43}$ Rumours and reports, accounts of information circulating between colleagues and neighbours, frequently appeared as

\footnotetext{
${ }^{40}$ ABF 1060200105/61, Banque Continentale (letter 27 October 1882)

${ }^{41}$ ABF 1060200105/61, Letter from Mme. Blu, Ambérieu-en-Bugey, 19 November 1903; Banque de Crédit des Valeurs à Lots (letter from M. Candelier, Arras, 4 November 1887).

42 ABF 1060200105/61, La Participation Financière (letter 14 November 1887).

${ }^{43}$ ABF 1060200105/61, Docks Commerciaux et Agricoles (letter 25 July 1882); Banque Victoria, Letter from Joseph Meyer, Joseph Carl, and Arigon, 15 March 1883.
} 
explanations for investment decisions and as reasons for claiming the Bank's attention. From Reims, Alexis Regnaudot explained that "some people are telling me that the company is worthless" while from Saint-Dié (Vosges), Laurence Frémy tried to recoup her investments with the Caisse Générale following worrying information about the company "gathered by other subscribers. $" 44$ Gesturing to broader constituencies of concerned individuals was no doubt in some cases a tactic that aimed to increase the perceived scope of the issue and thus the likelihood of a reply. Comments like Emile Henriot's, writing in 1899 to check on securities sold by the Caisse Nationale de Lyon, could also serve to generalize culpability and relativize a writer's individual error and embarrassment, as he observed ruefully that, "I'm learning that many people have fallen victim in these kinds of operations." 45

In these examples, letter writing provided a means for writers to reflect on and construct a social world of investment, if only discursively. But the practice of writing these letters was not uniformly a solitary or personal task. Letters occasionally came from groups (like the trio from Bordj Menaïel above) and several were penned by notables such as employers, notaries, and mayors acting on behalf of affected constituencies. From île d'Oleron in 1887, a municipal councilor wrote the Bank regarding the Caisse Générale Française d'Epargne, about which "numerous residents of the island who have purchased bonds want to be informed." 46 (He clearly hoped to leverage his office by inviting the Governor of the Bank to reply "confidentially" as to the brokerage's reliability.) In a similar fashion, D. Laufer, a shoemaker from Lausanne (Switzerland), explained that he was seeking information "not for myself, but for a host of labourers and a large number of my own workers who have selected this bank as their savings

\footnotetext{
${ }^{44}$ ABF 1060200105/61, Banque des Familles (letter 1 December 1884); Caisse Générale (letter 7 December 1882)

${ }^{45}$ ABF 1060200105/61, Letter from Emile Henriot, Maisons-Blanche, Algérie, 10 November 1889

${ }^{46}$ ABF 1060200105/61, Letter from Camille Berbudeau, Chéray, 24 May 1887
} 
institution [caisse d'épargne]. ${ }^{.47}$ In addition to their existence on the page, communities of modest investors were formed in part around these epistolary practices of solicitation and protest. This practice maps organically onto the vectors of authority and agency that constitute the world of the petition and "writing upwards," as the search for information and insight mobilized established hierarchies. But we can also see those relations being reconfigured. This form of finance was itself bypassing traditionally privileged intermediaries - which, one suspects, constituted a good part of its appeal. A notary from the town of Neuvy in central France, for example, wrote to the Bank of France in 1883 to lament that many of his clients had embarked on investments with one Caisse Populaire d'Epargne without consulting him - "they didn't come to ask my opinion until it dawned on them that they may have been duped" - though he hoped it wasn't too late for him to intervene. ${ }^{48}$ So, too, did the practices of direct address to the Bank of France offer letter writers a mode of supplementing but also evading the mediation of local authorities.

Communal or collective aspects of investment were also reflected in the ways writers spatialized their descriptions of financial practice, contextualizing investment in specific networks and geographies. Letters were powerful tools in this respect, as they traversed the physical and social distance separating a provincial investor from the country's financial capital. Writers described "brokers circulating in our countryside," or "our regions" (emphasis added) and recounted how "agents from a Parisian bank came through our area last February." 49 The firms about which writers inquired were always identified by their address (nearly uniformly a

\footnotetext{
${ }^{47}$ ABF 1060200105/61, Banque Victoria, letter undated.

${ }^{48}$ ABF 1060200105/61, Caisse Populaire d'Epargne (letter from Henri Lorion, Neuvy, 20 October 1883)

${ }^{49}$ ABF 1060200105/61, Letter from Adolphe Lambert, Soulaucourt, 4 May 1886; Banque d'Aumale (letter from Sylvestre Cartier, Lachamp-Condillac, 17 February 1884); Banque Continentale (letter from Béguin-Duchateau, Crécy-sur-Serre, 26 June 1883).
} 
street address in Paris), and the distance between the writer and the firm, as well as the writer's lack of familiarity with the capital, were common justifications for writing directly to the Bank of France. (Recall Savournin: “As I know no one in Paris, I write to you...”) A latent sense of provincial disadvantage in the financial arena occasionally became explicit, as writers presented their lack of information and confidence as a distinctly rural problem. One M. Duzon, an oyster merchant from the small town of Chaillevette (Charente-Maritime), excused himself for bothering the Bank's Governor in November 1884 but explained that, "us rural folk, we need guidance," while a year later, a grocer from Prouilly (Marne) expressed similar concerns, that "in the countryside we are often defrauded and never have enough information." 50 The letters reveal a countryside remarkably rich in financial news, discussion, and opportunity. At the same time, this networked terrain was experienced as uneven and unequal, defined less by the flood of gazettes and armies of brokers than by the ways that (good) information seemed to stop flowing.

In these letters, the Bank's particular capacity lies in its mastery of information, its capacity to know the market, both at a distance and close up. This is clearly evident in requests for general advice, which presume the Bank to be as well informed about affairs in small towns on the coast as about goings-on at the Paris Exchange. For writers pursuing information on their contracted investments, the Bank's informational advantage was still more immediate. The Governor and his employees were in a position to restore security and peace of mind with a simple glance through their records. Writers are cognizant of their disadvantage, feeling left behind by geographical distance and inexperience, the speed of their understanding outpaced by current events. They ask repeatedly to be put "au courant" of their affairs; they address the head of the Bank as uniquely "au courant" of financial matters; and cast their own capacities as out of

\footnotetext{
${ }^{50}$ ABF 1060200105/61, Banque de Crédit des Valeurs à Lots; Letter from Herbemont Auzellier, Prouilly, 23 December 1884.
} 
step with the situation: "je ne suis pas bien au courant de ces choses là" or " $n$ 'étant pas au courant de ces affaires. ${ }^{" 51}$ Writers had often written fruitlessly to other sources and authorities for assistance, and their mounting unease could be palpable, shining through the rote formulas of correspondence. A letter sent by a woman in Nice named Deprat in 1883 shows the writer reasoning with herself on the page as she works through her anxieties about her investments with the Banque Victoria. "A few days ago, "she writes, "I was told that the bank was struggling; since so many people love to run down the banks and their ways of operating, I don't take the reports too seriously. And yet, since I have money engaged with them, I would be very grateful if you, Monsieur le Directeur, better informed than anyone on these kinds of operations by virtue of your highly placed position, would kindly inform me." Your advice on this matter, she continued, "would reassure me." 52

The letter form investors adopt - writing to the head of the Bank of France in person - is one element of a more general rush to the real evident in their writings. Letter after letter, as writers articulate a need - a demand - to know the truth of their situation, they express themselves in an obsession with the material and the real as guarantor of financial security. Are the bonds they purchased really in the Bank's possession? (Fig. 2) "If the coupons are in your possession please do let me know," a widow named Madame Charles wrote from Beaune (Côte d'Or), "because the extended delay in receiving possession [note the re-emphasis on possession] makes me worried that there has been an error or oversight." ${ }^{53}$ Letters carefully list the details of specific bonds, stringing out serial numbers, specifying the year of the loan to which the writer

\footnotetext{
${ }^{51}$ ABF 1060200105/61: “je vous écris ces quelques mots pour que vous me metiez aux courant [sic]" (Urbain Armellin, Marseille, 29 January 1883); "Pensant que vous devez être au courant de cette affaire mieux que tout autre" (Hortense Bodart, Calais, 17 December 1885); Banque Victoria (Madame Deprat, Nice, 22 October 1883); Letter from Isaac Marignan, Milhaud, 4 July 1885.

${ }^{52}$ ABF 1060200105/61, Banque Victoria

${ }^{53}$ ABF 1060200105/61, Caisse Populaire d'Epargne (letter 10 February 1884)
} 
subscribed. Are those bonds, they want to know - those exact bonds, not ones like them physically at the Bank? They have enough to complete the final payments in advance; can they come collect them now? A rather choppily written letter from a small-town mayor in 1882 captures this emphasis on the tangible. Explaining the purchasing process, he stresses that the company concerned "sold me the bonds on credit, on a payment plan and will deliver the securities into my hands only upon full payment;" later, he explains, "I asked them to give me those securities into my hands" only to receive the reply that "they could not sell me the securities whose numbers they had put into my hands." This left him reaching out to the bank, recounting "the serial numbers that I have in my hands" to the Governor of the Bank (emphasis added). ${ }^{54}$ The specificity of the instruments was part of the writers' contractual claim; as is seen here, brokers occasionally tried to fob off clients with different bonds than the ones they had committed to buy. But this specificity had importance beyond the legal or bureaucratic. Along with lists of family members, it assisted investors with personalizing their claim. At the same time, it reflected the importance of the material to the experience of being an investor. From the appearance of advertising and sales contracts to the tangible possession of the security itself, for these investors investment was concrete and physical in significant ways - otherwise the aesthetics of sales contracts and bonds would not have received such dedicated attention from sellers, buyers, and legislators. (Fig. 3) The distance from their securities and the risk of dispossession at play in these transactions heightened this concern with the material object. Indeed, as a tool for assuaging the anxieties of absence - for negotiating the space and time of separation - the letter serves to amplify the disquiet that accompanies the dematerialization of the objects and relations of investment.

\footnotetext{
${ }^{54}$ ABF 1060200105/61, Comptoir Français de l'Epargne (letter from Vier [?], Maire de la Commune de Faÿ-lesNemours (Seine-et-Marne), 16 November 1882)
} 


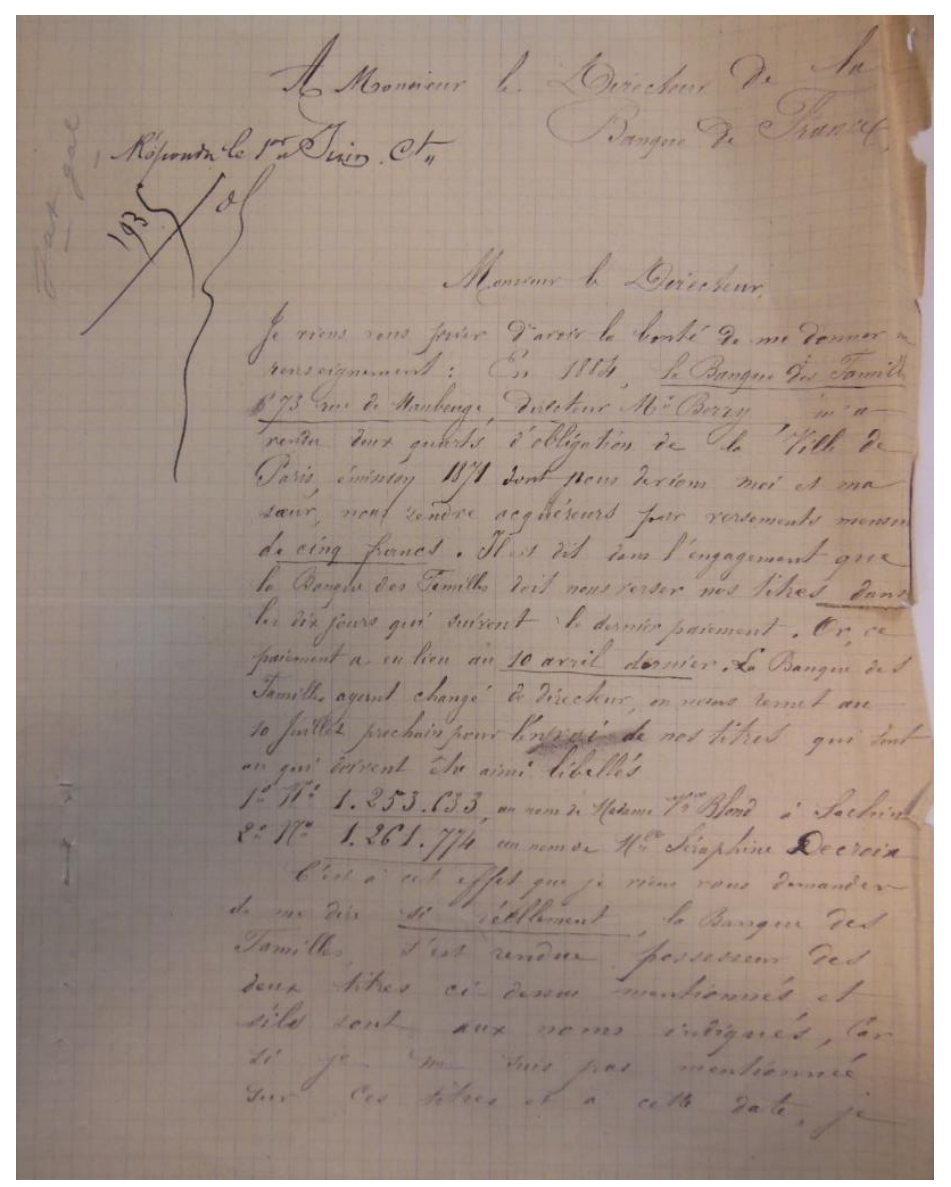

Figure 2: A letter signed Madame Veuve Blond, Sachin, Pas de Calais, c. 1 June 1887. Note the underline on the term "si réellement" in the final paragraph.

Source: Archives de la Banque de France 


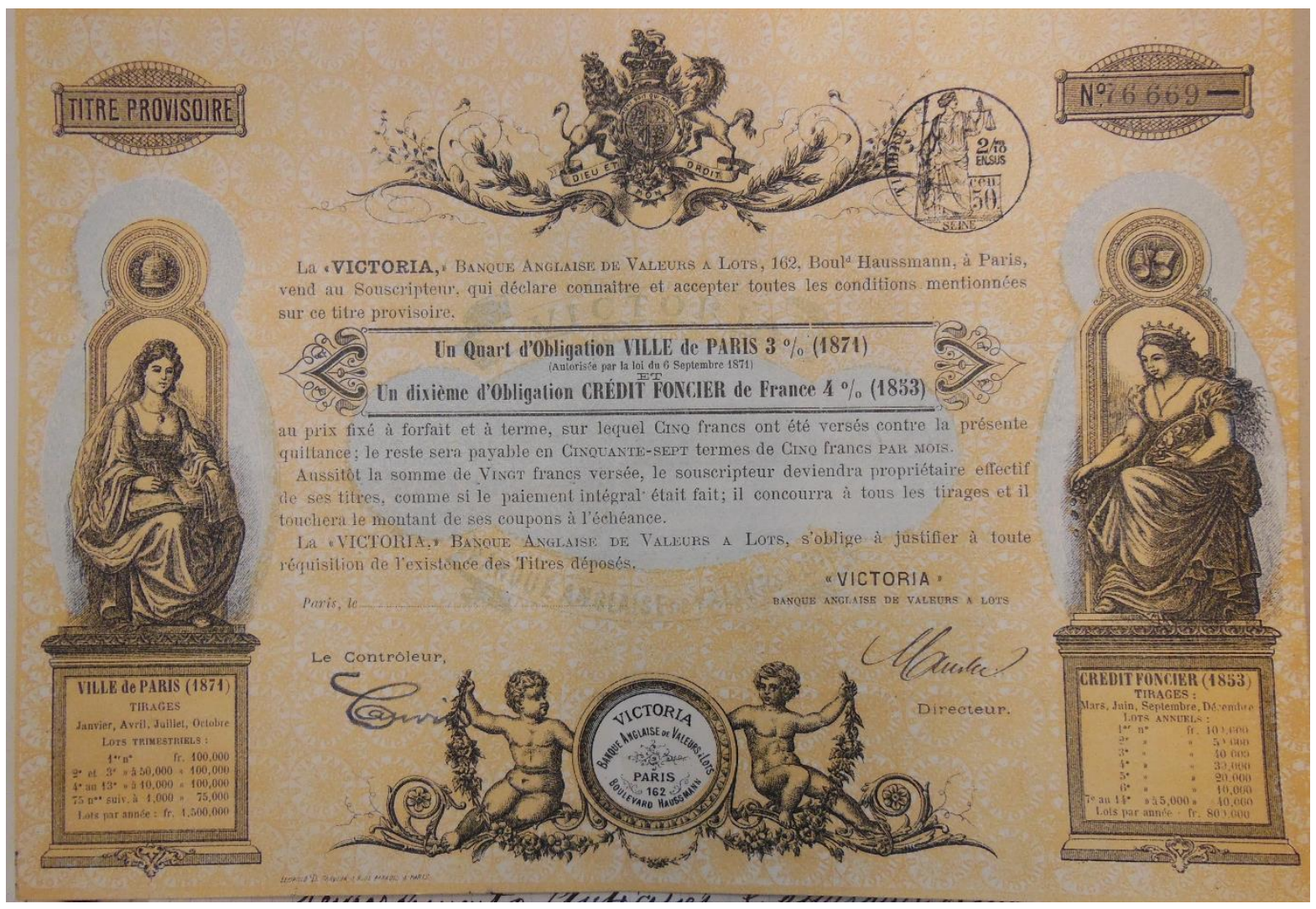

Figure 3: An example of a decorated sales contract (entitled a 'Provisional Certificate') for the purchase of a quarter City of Paris bond and a tenth Crédit Foncier from the Banque Victoria.

Source: Archives de la Banque de France.

In their letters, writers frequently refer to the bank's guarantee (as they understood it) as the deciding factor in their investment decision. After all, it was the Bank of France's role in these sales activities that generated much of this correspondence in the first place. An instructor at the prison in Nîmes insisted that he only subscribed to bonds from the Crédit Populaire on the express condition that the security would be on deposit at the Bank of France, while Julie Moisset and a M. Patron from the $11^{\text {th }}$ arrondissement in Paris swore in their complaint to the public prosecutor in 1887 that they would never have contracted with La Participation Financière without the firm's advertised claim that it had 100000 francs on deposit at the Bank of France. ${ }^{55}$

\footnotetext{
${ }^{55}$ ABF 1060200105/61, Crédit Populaire (letter from A. Laporte, Nîmes, 16 October 1885) ; La Participation Financière
} 
Such statements were often undoubtedly true - why else would brokers include references to the Bank of France's collaboration in their advertising and sales pitches? Yet invoking the Bank's guarantee was also tactical. It gestured to the esteem and influence of the Bank of France as an institution, currying favour with the recipient. More forcefully, it expressed a claim regarding the institution's responsibility, a responsibility that was potentially legal but more immediately moral. (Even while implicit, this claim was audible to the Bank of France. Internally, discussions of liability proceeded in precisely these terms.) Expressing faith in the guarantee of the Bank allowed the writer to signal their respectable intentions, to separate themselves from frivolous financial dabblers whose decisions might not be guided by serious reflection or oriented to longterm stability. It was one plank in a mode of appeal typical to the "writing upwards" genre: selfpresentation as a hard-working family provider and honest labourer whose toil warrants both reward and protection. ${ }^{56}$

This was an important rhetorical and argumentative move, with writers taking on the task of fitting finance and investment into the discursive world of labour and economic justice. Letter writers appealed to the Governor of the Bank to "shelter a worker's modest savings from danger," to "save a small employee and head of a family [père de famille] from worry," or to protect "a simple garden farmer [...] for whom acquiring a few savings was a trial." 57 They leashed their decisions to the long durée of the working life. The past - a productive past, a laborious past - weighed heavily in writers' accounts of their actions and requests for information. Asking after their securities, they commonly linked the grueling (but honourable)

\footnotetext{
${ }^{56}$ For diverse contexts, see Fitzpatrick, "Supplicants and Citizens;" Fassin, "La Supplique. Stratégies rhétoriques et constructions identitaires." On the related genre of petitioning, see Agnès, "Le 'Pétitionnaire universel"”; De and Travers, "Petitioning and Political Cultures in South Asia"; Miller, "The Transformation of Petitioning in the Long Nineteenth Century."

${ }^{57}$ ABF 1060200105/61, Banque Lyonnaise de Capitalisation et d'Epargne (letter from Ed. Fievot, Troyes, 15 December 1886); Caisse Générale des Familles d'Epargne et de Crédit (letter from A. Jacquier, Reims, 6 December 1882); L’Union Foncière (letter from Michel Maigret, Lyon, 22 February 1895)
} 
work of their preceding years with the justified ease and prosperity of their, and their families', future. When investments seemed to have failed, the fear and shock was expressed as a temporal break, a fissure between years of labour and expected (and hoped for) futures, cut off by a flash of instantaneous ruin. "Please do whatever you can, Monsieur le Gouverneur, to have my situation resolved," a chef armurier in the army named Danilo wrote in 1881, "for the value of these securities represents the fruit of all my savings to the present day, and it would be truly unfortunate if I have sacrificed only for other people's profit and to see myself thus reduced to misery." ${ }^{, 58}$ Pasts were wasted, futures foreclosed. As a tax employee from Bordeaux explained, mirroring Danilo’s prose: “This sum comes entirely from my modest savings for my child it would be very unfortunate for me to see it collapse so miserably." 59 The language of 'les petits' is a refrain throughout the collection - petites économies, modeste situation, humble habitant, pauvre ouvrier - embraced for its political potency and ability to frame investment in terms of production and utility. ${ }^{60}$ It also inflected the spatialization discussed above, in which the virtuous provinces of "petites localités" stood opposed to - possibly victimized by - the rapacious capital to which the letters were directed. ${ }^{61}$

These positionalities and personas may or may not be accurate; they reappear so consistently in part because they perform effective work of explanation and persuasion. Savvy letter writers appealing to the "goodness," "wisdom," and "benevolence" of the Governor of the Bank were applying rhetoric and narrative that they believed would deliver their desired outcomes, rather than necessarily expressing deeply felt sentiments of deference. Nevertheless, at a minimum these strategies involved momentary assertions of social identity that were

\footnotetext{
${ }^{58}$ ABF 1060200105/61, Petit Rentier

${ }^{59}$ ABF 1060200105/61, Union Syndicale des Porteurs de Titres (letter from Latour, 23 November 1887)

${ }^{60}$ Birnbaum, Le peuple et les gros.

${ }^{61}$ ABF 1060200105/61, Docks Commerciaux et Agricoles (letter from F. Ruault, Barenton, 22 January 1883)
} 
potentially consequential for how writers appreciated their experience of finance. Moreover, the application of such common tropes can be laced through with revealing elements of both argument and experience. The language of fraud to which writers had frequent recourse expressed both victimization and contrition: "I am a poor widow who let herself be taken in by an agent from the Docks Commerciaux;" "last April I let myself be seduced by a circular," "I let myself be taken in by an agent's smooth talking" (emphasis added). ${ }^{62}$ These letters, penned to a distant and esteemed, but unknown, individual, could take on the quality of the confessional. Describing themselves as actual or potential "dupes," writers acknowledged their part in the affair and awaited judgement and - vitally - deliverance. At no point did a letter-writer make any defensive or justificatory statement that might suggest the multiplication of these savings through prudent investment was anything other than legitimate and respectable - indeed, ordinary. Investing was aspirational behavior; "I ask nothing better than to invest my money," one Charles Suret wrote from Cherbourg in $1883 .{ }^{63}$ There are also hints of more assertive concerns with rights, rather than requests for services. As Patron concluded in his exposition on to the Bank, the institution "ought to take all possible measures to protect the small savings of the truly deserving class." ${ }^{\prime 64}$ This 'class' - small savers turned small investors - had a legitimate claim on the support of the country's highest economic institutions.

This support was paltry, in either moral or financial terms. Given their urgency to glean some insight into the fate of their savings - one Petit Girard Ferjeux offered the Bank fifty francs for its troubles, considering that a small fee compared to "the thousand francs [at risk] for a poor

\footnotetext{
${ }^{62}$ ABF 1060200105/61, Docks Commerciaux et Agricoles (letter from Veuve Keusch, Belfort, 20 March 1883); Union Syndicale des Porteurs (letter from Mulot, Saultain, 14 October 1887); Banque de Crédit des Valeurs à Lots (letter from M. Candelier, Arras, 4 November 1887)

${ }^{63}$ ABF 1060200105/61, Banque Victoria (letter from 11 May 1883)

${ }^{64}$ ABF 1060200105/61, La Participation Financière, plainte de Patron et Moisset, 1887.
} 
worker who earned them by his own hands" - writers were undoubtedly frustrated by the Bank's replies. ${ }^{65}$ In nearly all cases, it refused to provide assistance, particularly if what the writer required was information on a client's (broker's) deposits. In its view, "secret professionnel" laws constraining certain professions from sharing client information with third parties - forbade disclosure of such matters. Replies were brisk, standardized; most of the letters in this collection are marked with penciled notations from clerks allocating a 'lettre habituelle' or 'réponse ordinaire', which consisted of a few lines stating that the Bank of France could not divulge the requested information and had no connection to the firms in question.

In their words and style, these form responses declined responsibility and discouraged further engagement, departing sharply from the moralistic - even melodramatic - tone that inquiries could exhibit. By failing to reciprocate the register and format of a correspondent's letter, the Bank's letters refused the invitations to personalization and confession which writers extended. The process was deliberate and laborious, with drafts showing the process of disciplining epistolary exchange. Notes for the reply sent to Jean-Pierre Etchelécu in February 1886, for example, read "Get information on the Banque Victoria. This man has been duped try to be helpful to him;" but the impulse never reached paper, as he nevertheless received a standard reply. ${ }^{66}$ For a reply to the mayor of Fäy-les-Nemours, we find the notes: "The securities in question are not on deposit. However, it is possibly problematic to give this information precisely to the correspondent. We should perhaps write that the Bank does not divulge information on its deposits, but that in any event, if the securities were on deposit they would be entirely at the disposal of the depositor." ${ }^{67}$ Writers awaiting insight and validation doubtless

\footnotetext{
${ }^{65}$ ABF 1060200105/61, Crédit National (Letter from Petit Girard Ferjeux, Miellin, 19 March 1883).

${ }^{66}$ ABF 1060200105/61, Banque Victoria (Reply to Jean-Pierre Etchelécu, Domezain, 19 February 1886)

${ }^{67}$ ABF 1060200105/61, Comptoir Français de l'Epargne, Note by E. Desmarest [2e sous-gouverneur de la Banque de France], November 1882.
} 
experienced keen disappointment. One correspondent, Madame Widow Blond, went to lengths to recount the purchase and long payment period for bonds from the Banque des Familles that were intended for herself and a Mademoiselle Séraphine Decroix (likely a female relative; the bank assumed in its response that it was her sister). The bank's curt reply - "I regret to inform you that the transaction you describe does not concern the Bank of France in any way and that it is impossible to reply to your question" - was incommensurate with her careful exposition. ${ }^{68}$ If these letters were performing an assertion of identity, this dead end of correspondence denied its expression. Feelings of loss and uncertainty were no doubt compounded; anger was another possibility. These small investor letters often communicated feelings of being left behind, shut out from opportunities that seemed easily available and fruitful for others; now another door the face of a filing cabinet, the cover of an archival dossier - slammed in their faces.

\section{Conclusion}

The investor letters surveyed in this article are simultaneously rich and thin documents. They do not constitute an ongoing correspondence, with exchanges over time that develop and express particular subjectivities. There remains a great deal that we do not know about the authors, which obscures the relative magnitude of their struggles and prevents us from fitting the actions they recount into longer experiences and broader perspectives in the mode of the social historian. Yet they share variants of a common calamity and draw on a set of common strategies to attempt a rescue. Their letters show the world of finance to have been an epistolary world; letters to brokers, to agents, to lawyers affected the frequent exchanges necessary to carry out and monitor investment, while the financial offices of the postal bureau and telegraph station sent money orders for purchases and redemption. However terse individually, as a genre these letters

${ }^{68}$ ABF 1060200105/61, Banque des Familles (letters from June 1887) 
provided sites where writers worked out how they might operate as investors, sketching rationales for their decisions, mapping potential entitlements, seeking validation for their decisions; in short, they represent moments of economic self-consciousness. Studies of the spread and legitimation of financial markets in the nineteenth century tell us much about the way those markets, via the writings of economists, journalists, and other financial popularizers, spoke to potential publics, suggesting appropriate modes for engagement - importantly, the rational and calculative mode. But in addition to key studies of how the market is represented to people, investor letters are examples of how people engage with those representations and present themselves back to 'the market.' If their argumentation is not strictly calculative, these letters present their authors as entitled members of the financial public, cautious, endowed with agency, and owed a place at the table.

As with Steedman's investigation of letters and the everyday use of the law in the nineteenth century, these missives provide an opportunity to "hear better" conversations about a seemingly obscure and distant field of activity, one seldom associated with the lower or commoner sorts of people. ${ }^{69}$ One cannot leave off these letters without a powerful impression of the extent and diversity of financial practice in which their authors engaged as a matter of course. Importantly, we gain a toehold in the world of female investors in France, a group whose existence and activities have yet to receive substantial analysis. These letters to the Bank of France were among many that preoccupied such people as they sought ways to protect and shepherd their savings in a moment of profound capitalist transition. As elements of everyday practice, they both show and effected the embeddedness of financial affairs in daily routines, writing novel financial mechanisms - whether instruments like a tenth of a Crédit Foncier bond

\footnotetext{
${ }^{69}$ Steedman, “A Lawyer's Letter,” 64.
} 
or a payment program offered by a traveling salesman - into ordinariness (even as the results of these operations were far from what participants expected). They also reveal the intensely spatialized, peopled, and personal nature of that arena; encounters with the market took place via gazettes that were hand-delivered, brokers who entered homes and pulled up chairs in cafes, and were personified in the persons of the heads of the nation's central monetary institution $-\mathrm{M}$. le Gouverneur, or M. le Directeur. Workmates discussed investment opportunities together and local mayors penned inquiries on behalf of 'their' localities. These were the realities and rationalizations that made it possible for ever increasing numbers of people to find themselves engaging as investors in national (and soon, international) financial markets.

The men and women drafting these letters were infinitesimal agents in the financial economy. But they were agents. These letters became part of the informational infrastructure of modern finance. Though rarely communicated to correspondents (which can make for bittersweet reading) scribbled notes and internal reports show that Bank employees followed up on the assets and activities of agencies these letters brought to their attention, checking on their deposits, credit advances, and chequing accounts. Writers' predicaments and complaints spurred the Bank to modify its policies, to pursue brokers who falsely deployed its name as a marketing tool; by 1887, the Bank's own legal team recommended prohibiting advances on securities deposited by all installment sales agencies: "Its abstention would paralyze an industry that quite often can operate only with its support, and which in nearly all cases is nothing but a trap dangled before the small saving class."70 Rather than suggest that the particularities of how these letter writers discerned the workings of the financial marketplace - their emphasis on particular spaces and tangible things, for instance - were marginal or idiosyncratic, these writings prompt

\footnotetext{
${ }^{70} \mathrm{ABF}$ 1060200105/67, Note pour Monsieur le Gouverneur, Avances demandées sur valeurs à lots vendues à crédit à des tiers, J. Guillaume, Chef de Contentieux, 21 mars 1887.
} 
us to reconsider where the margins of finance really lay. The borders of (judicial, moral) legitimacy that so preoccupy legal and sociological scholars of the market do not seem to have registered as breaks in the economic practices of ordinary people. Nor did the small (marginal) amounts of capital at stake in these transactions prevent men and women from inserting their demands onto the agendas of the country's national economic institutions. Emma Rothschild's ongoing study of eighteenth-century Angoulême calls the notion of margins into question, demonstrating that global commerce and imperial migration composed networks of people, goods, and information which ensured that the global economy was salient even for humble individuals. ${ }^{71}$ These investor letters similarly suggest that the activities of those far from the central icons of finance - the Exchanges and the banks of Paris - are far from marginal to the unfolding of financial institutions and financialized worldviews.

\section{Acknowledgments}

The author thanks the anonymous reviewers and guest editors of this issue of French Historical Studies, whose suggestions were consistently insightful, provocative, and valuable. She is also grateful to the staff of the Bank of France archives, and for feedback from the Research Triangle French History and Culture Seminar and colleagues at the University of Manchester's Centre for Economic Cultures.

\section{Contributor's Note}

Dr. Alexia Yates is Senior Lecturer in Modern History at the University of Manchester. She researches urban history and the history of economic life in modern France. Her most recent

\footnotetext{
${ }^{71}$ Rothschild, "Isolation and Economic Life."
} 
book is Selling Paris: Property and Commercial Culture in the Fin-de-siècle Capital (Harvard University Press, 2015).

\section{References}

Aglan, Alya, Olivier Feiertag, and Yannick Marec, eds. Les Français et l'argent, XIXe-XXIe siècle: Entre fantasmes et réalités. Rennes, 2011.

Agnès, Benoît. 'Le 'Pétitionnaire universel': les normes de la pétition en France et au RoyaumeUni pendant la première moitié du XIXe siècle," Revue d'histoire moderne et contemporaine 58 no.4 (2011) : 45-70.

Agnès, Benoît. "Le solliciteur et le pétitionnaire: infortunes et succès d'une figure sociale et littéraire française (première moitié du XIXe siècle)," Revue historique 661 (2012): 27-47.

Beachy, Robert, Béatrice Craig, and Alastair Owens, eds., Women, Business, and Finance in Nineteenth-century Europe: Rethinking Separate Spheres. Oxford, 2006.

Bignon, Vincent and Marc Flandreau, "The Economics of Badmouthing: Libel Law and the Underworld of the Financial Press in France Before World War I," The Journal of Economic History 71 no. 3 (2011): 616-53.

Birnbaum, Pierre. Le peuple et les gros: Histoire d'une mythe. Paris, 1979.

Bouvier, Jean. Les Deux scandales du Panama. Paris, 1964.

Breton, Yves, Albert Broder, and Michel Lutfalla, eds. La longue stagnation en France: L 'autre grande dépression, 1873-1897. Paris, 1997.

Chotard-Lioret, Caroline. "Correspondre en 1900, le plus public des actes privés, ou la manière de gérer un réseau de parenté,” Ethnologie française 15 no.1 (1985): 63-72.

Christen-Lécuyer, Carole. Histoire sociale et culturelle des Caisses d'Épargne en France: 18181881. Paris, 2004.

Clément, Jules. Le Nouveau secrétaire, Traité général de la Correspondance. Paris, 1871.

Cohen, Deborah. "Love and Money in the Informal Empire: The British in Argentina, 1830 to 1930," Past \& Present 245 no.1 (2019): 79-115.

Craig, Béatrice. Female Enterprise Behind the Discursive Veil in Nineteenth-Century Northern France. London, 2017. 
Crossick, Geoffrey and Heinz-Gerhard Haupt, eds., Shopkeepers and Master Artisans in Nineteenth-century Europe. London, 1984.

Dauphin, Cécile. Prête-moi ta plume: Les manuels épistolaires au XIXe siècle. Paris, 2000.

De, Rohit and Robert Travers, "Petitioning and Political Cultures in South Asia: Introduction." Modern Asian Studies 53 no.1 (2019): 1-20.

Ditz, Toby. "Formative Ventures: Eighteenth Century Commercial Letters and the Articulation of Experience," in Epistolary Selves: Letters and Letter-writers 1600-1945, edited by Rebecca Earle, 59-77. Aldershot, 1999.

Fassin, Didier. "La Supplique. Stratégies rhétoriques et constructions identitaires dans les demandes d'aide d'urgence," Annales: Histoire, Sciences Sociales 55 no.5 (2000): 955-981.

Fitzpatrick, Sheila. "Supplicants and Citizens: Public Letter-Writing in Soviet Russia in the 1930s," Slavic Review 55 no.1 (Spring 1996): 78-105.

Freedeman, Charles. The Triumph of Corporate Capitalism in France, 1867-1914. Rochester, 1993.

Garcia-Parpet, Marie-France. "The Social Construction of a Perfect Market." In Do Economists Make Markets? On the Performativity of Economics, edited by Donald MacKenzie, Fabian Muniesa, and Lucia Siu, 20-53. Princeton, 2007.

Garrigues, Jean. La République des hommes d'affaires. Paris, 1997.

Hautcoeur, Pierre-Cyrille, ed. Le Marché financier français au XIXe siècle. T. 1: Récit. Paris: 2007.

Hautcoeur, Pierre-Cyrille and Angelo Riva, "The Paris Financial Market in the 19th Century: Complementarities and Competition in Microstructures," Economic History Review 65 (November 2012): 1326-1353.

Hissung-Convert, Nelly. La Spéculation boursière face au droit 1799-1914. Paris, 2009.

Hochfelder, David. "Where the Common People Could Speculate: The Ticker, Bucket Shops, and the Origins of Popular Participation in Financial Markets," Journal of American History 93 no. 2 (September 2006): 335-358.

Khan, B. Zorina, "Invisible Women: Entrepreneurship, Innovation, and Family Firms in Nineteenth-century France,” The Journal of Economic History 76 no.1 (March 2016): 163-195.

King, Steven. Writing the Lives of the English Poor, 1750s-1830s. Montreal and Kingston, 2019. 
Labardin, Pierre and Paulette Robic, "Epouses et petites entreprises: Permanence du XVIIIe au XXe siècle," Revue Française de Gestion, nos.188-189 (2008): 97-117.

Laurence, Anne, Josephine Maltby, and Janette Rutterford, eds., Women and their Money, 17001950. Essays on Women and Finance. New York, 2009.

Lipartito, Ken. "Connecting the Cultural and the Material in Business History," Enterprise and Society 14 no.4 (2013): 686-704.

Locker, Kitty. ““'Sir, This Will Never Do:” Model Dunning Letters, 1592-1873,” International Journal of Business Communication 22 no. 2 (1985): 39-45.

Lyons, Martyn. Reading Culture and Writing Practices in Nineteenth-century France. Toronto, 2008.

Lyons, Martyn. "Writing Upwards: How the Weak Wrote to the Powerful," Journal of Social History 49, no.2 (2015): 317-330.

MacKenzie, Donald. An Engine, not a Camera: How Financial Models Shape Markets.

Cambridge, MA, 2006.

Miller, Henry. "Introduction: The Transformation of Petitioning in the Long Nineteenth Century (1780-1914)," Social Science History 43 no.3 (2019): 409-429.

Ministère du Travail et de la Prévoyance Sociale, Album graphique de la statistique générale de la France. Résultats statistiques du recensement de 1901. Paris, 1907.

Ministère de l'Agriculture et du Commerce, Direction de la statistique générale, Annuaire statistique de la France. Paris, 1883.

Murphy, Anne, ed., The Worlds of the Jeake Family of Rye, 1640-1730. Oxford, 2018.

Neymarck, Alfred. Le Développement annuel de l'épargne française. Le Crédit de l'état, leur rapport et leur utilité pour notre commerce et notre industrie. Paris, 1906.

Nord, Philip G. Paris Shopkeepers and the Politics of Resentment. Princeton, 1986.

Piketty, Thomas, Gilles Postel-Vinay, Jean-Laurent Rosenthal, "Wealth Concentration in a Developing Economy: Paris and France, 1807-1994," The American Economic Review 96, no.1 (2006): 236-256.

Piketty, Thomas, Gilles Postel-Vinay, Jean-Laurent Rosenthal, "Inherited vs. Self-made Wealth: Theory and Evidence from a Rentier Society (Paris 1872-1927)," Explorations in Economic History 51 (2014): 21-40.

Poovey, Mary. "Writing about Finance in Victorian England: Disclosure and Secrecy in the Culture of Investment," Victorian Studies, 15 (Autumn 2002): 17-41. 
Popp, Andrew and Robin Holt, "Entrepreneurship and Being: The Case of the Shaws," Entrepreneurship and Regional Development 25 (January 2013): 52-68.

Poublan, Danièle. "Affaires et passions. Des lettres parisiennes au milieu du XIXe siècle," in $L a$ Correspondance: Les usages de la lettre au XIXe siècle, edited by Roger Chartier, 373-406. Paris, 1991.

Preda, Alex. "The Rise of the Popular Investor: Financial Knowledge and Investing in England and France, 1840-1880" The Sociological Quarterly 42, no.2 (2001): 205-232.

Preda, Alex. "The Investor as a Cultural Figure in Global Capitalism," in The Sociology of Financial Markets, edited by Karin Knorr-Cetina and Alex Preda, 141-162. Oxford, 2004.

Reffait, Christophe. La Bourse dans le roman du second XIXe siècle. Discours romanesque et imaginaire social de la spéculation. Paris, 2007.

Richez, Sébastien. "Le Facteur rural des postes en France avant 1914: Un nouveau médiateur au travail," Le Mouvement Social 218, no.1 (2007): 29-44.

Robb, George. Ladies of the Ticker: Women and Wall Street from the Gilded Age to the Great Depression. Urbana, IL., 2017.

Rothschild, Emma. "Isolation and Economic Life in Eighteenth-century France," The American Historical Review 119 no.4 (2014): 1055-1082.

Rowe, Steven E. "Writing Modern Selves: Literacy and the French Working Class in the Early Nineteenth Century," Journal of Social History 40 no.1 (2006): 55-83.

Rutterford, Janette, David R. Green, Josephine Maltby, and Alastair Owens, "Who Comprised the Nation of Shareholders? Gender and Investment in Great Britain, c. 1870-1935," The Economic History Review, 64 no.1 (2011): 157-187.

Sandage, Scott. Born Losers: A History of Failure in America. Cambridge, MA, 2006.

Sokoll, Thomas. "Writing for Relief: Rhetoric in English Pauper Letters, 1800-1834," in Being Poor in Modern Europe: Historical Perspectives, 1800-1940, edited by Andreas Gestrich, Steven King, and Lutz Raphael, 91-112. Oxford, 2006.

Stanziani, Alessandro. Dictionnaire historique de l'économie-droit, XVIII-XXe siècles. Paris, 2007.

Steedman, Carolyn. “A Lawyer's Letter: Everyday Uses of the Law in Early Nineteenth-century England," History Workshop Journal 81 no.1 (2016): 62-83.

Summerfield, Penny. Histories of the Self: Personal Narratives and Historical Practice. London, 2018. 
Thompson, Victoria E. The Virtuous Marketplace: Women and Men, Money and Politics in Paris, 1830-70. Baltimore, 2000.

Todd, David and Alexia Yates. "Public Debt and Democratic Statecraft in Nineteenth-Century France" in A World of Public Debts: A Political History, edited by Nicolas Delalande and Nicolas Barreyre. London, 2020.

Tomkins, Alannah. "“I Mak Bould to Wrigt:” First Person Narratives in the History of Poverty in England, c.1750-1900," History Compass, 9 (2011): 365-373.

Trivellato, Francesca. The Familiarity of Strangers: The Sephardi Diaspora, Livorno, and Crosscultural Trade in the Early Modern Period. New Haven, CT, 2009.

Walton, Charles. “Capitalism's Alter Ego: The Birth of Reciprocity in Eighteenth-Century France," Critical Historical Studies 5 no.1 (2018): 1-43.

Zdatny, Steven. The Politics of Survival: Artisans in Twentieth-century France. New York, 1990. 